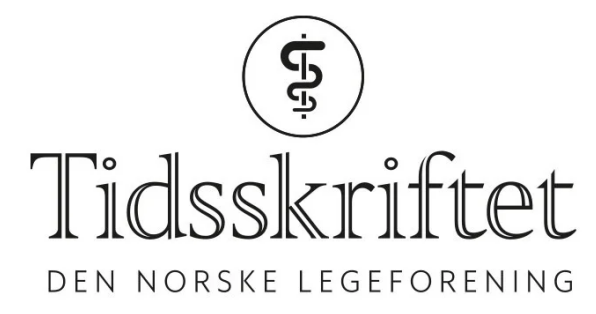

\title{
Kusmaepidemi i Steigen
}

TIDLIGERE I TIDSSKRIFTET

JULIE DIDRIKSEN

julie.didriksen@tidsskriftet.no

Tidsskriftet

Parotitt er en betennelse i ørespyttkjertelen som vanligvis forårsakes av kusmavirus. Grunnet effektiv vaksinering ser vi ikke dette så ofte lenger, men det var jevnlig utbrudd i Norge tidligere. I Tidsskriftet nr. 5/1901 sto en beretning fra Steigen legedistrikt, der sykdommen også ble omtalt som «Kindtaske» (Tidsskr Nor Lægeforen 1901; 21: 243-8).

«Kindtaske». 


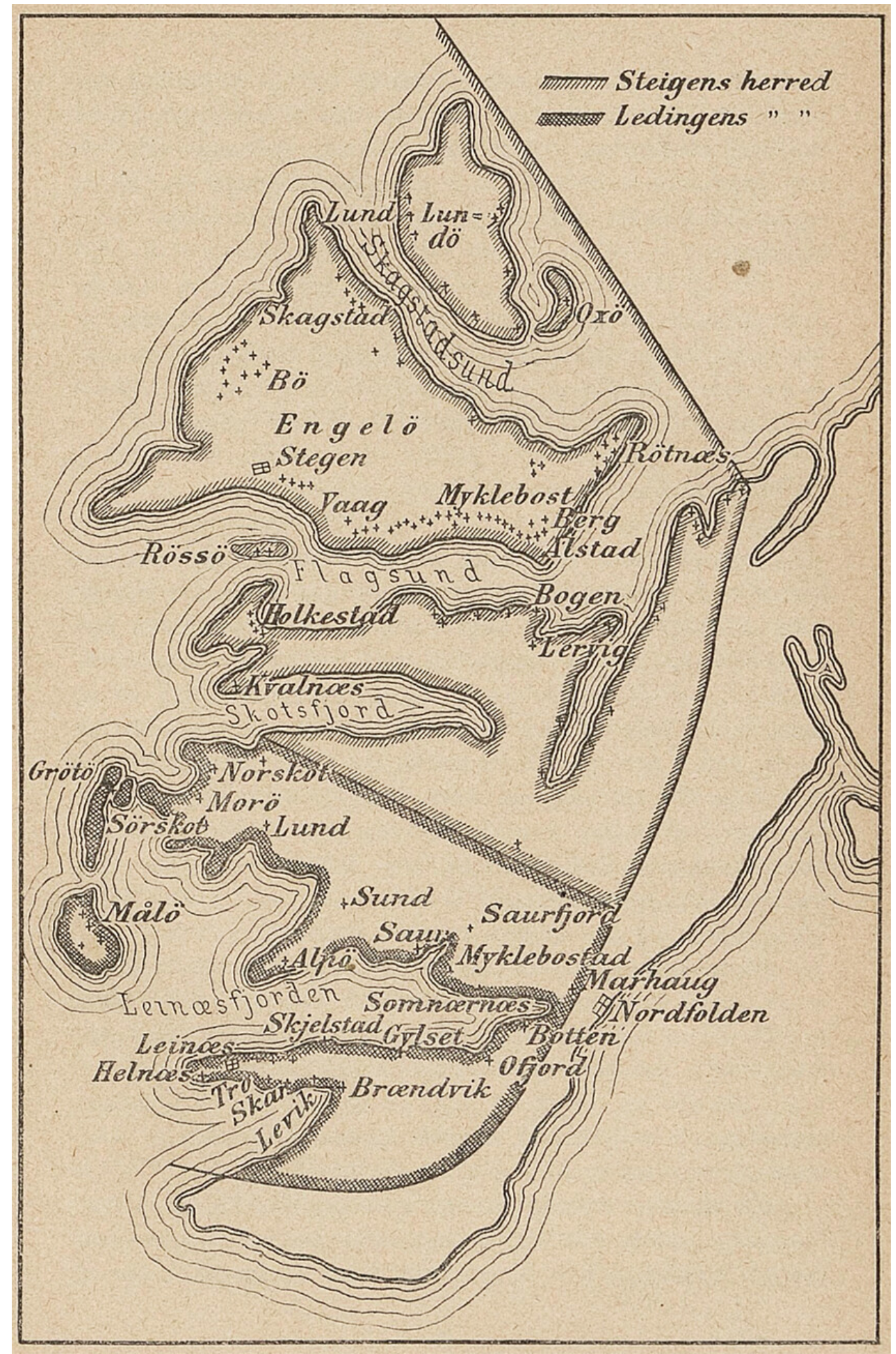

Illustrasjon fra faksimile

I betragtning av, at der aldrig i tidsskriftet sees noget om parotit, vil vel følgene oplysninger om sygdommen i Steigens lægedistrikt kunne påregne interesse som kuriositet.

Distriktet omfatter Steigens - 2416 indb. - og Ledigens - 1255 indb. - herreder. For Ledingens vedkommende er de store trafikcentrer kirkestedet Leinæs og handelsstedet Grøt $\varnothing$ - det første om hverdagene, det sidste de søndage, der er gudstjeneste. Hvad åstederne for sygdommens optræden forøvrigt angår henvises til kartskissen, der er holdt saa schematisk som muligt. 
Det første kendte tilfælde av parotit iagttoges 29/8 hos en utensognshåndverker, der var i arbeide paa Grøtø; han reiste et par dage senere fra distriktet og smittede ingen her. Men i de første dage av mai kom en gut fra [en gård] hjem fra Lofoten (Sørvågen), og var da syk, og fra ham daterer epidemien sit utspring. I løpet av mai og juni optraadte nu syken på Sundgårdene; men ikke som noget husepidemi, der slang et tilfælde hist og her på gårdene. Så optræder syken i konfirmantskolen, der i juni og juli holdtes paa Leinæs, utenat der dog var nogen utbredt epidemi. Men efter konfirmationen, da børnene vender hjem, bryter syken ut med én gang på flere steder, fra 29de juli og utover på gårdene Nordskot, Sørskot, Lund og Alpø, i septbr. optræder den på sydsiden av fjorden i Brændvik; og i oktober og november går kusma omkring som en brølende løve søkende, hvem den kan opsluke. Sygdommen slår ned for fote; i et enkelt hus var samtidig 7 personer sengeliggende. På gårdene Sund, Lund, Sørskot og Norskot, hvor syken første gang bare hadde valgt sig et og andet bytte - og ovenikøpet behandlet vedkommende nogenlunde lempeligt, gjorde den ved sit andet besøk rent bord. Og ikke nok med det, foruten at infektionsstoffet syntes at være blit mere smitte-dygtigt, frembringer det også voldsommere symptomer. Endelig synes det, som virus taper i intensitet mot slutten av året - om det er fordi de klimatiske forhold forandrer sig, eller fordi det har passeret så mange, vet jeg ikke.

\section{«I oktober og november går kusma omkring som en brølende løve}

søkende, hvem den kan opsluke»

Til selve Steigen kom sygdommen først i november. Rygtevis berettes at sygdommen skal ha optrådt også her tidlig paa høsten; men dette har jeg ikke kunnet konstatere. Men i october og november optrådte den på de Grøtø nærmeste liggende gårdene i Steigen: Kvalnæs og Holkestad. På det første sted skal «næsten alle» ha været angrebne. På Holkestad foretok jeg under et besøk d. 20/12 en tælling, der utviste 21 angrebne, derav én som hadde ført sygdommen med sig fra Ofoten. Også på Lervik og på Røssø i Steigen har sygdommen optrådt som husepidemi, mens der ellers i herredet kun er optrådt et tilfælde hist og her mot årets slutning.

For at få en oversigt medgav jeg folketællerne i Ledingen schemata til utfyldning. Av hensyn til deres arbeide for øvrig, måtte disse gøres så enkles som muligt for at ikke sinke dem. Resultatet er følgende: (...) 28,2 pct. av herredets befolkning. Tællingen synes også at vise, at parotit ikke er noget eksvisit barnesygdom. - Sygdommen har tat, hvad der var av disponibelt (eller vel rettere disponeret) materiel, som lå i dens vei, endog en gammel pike på 60 år. Kun et tilfælde kendes, hvor sygdommen er optrådt for anden gang: hos en voksen mand, der for to år siden hadde søkt læge for kusma. - I selve Steigen antar jeg antallet av angrebne neppe kan sættes høiere end til 5o, hvorav hovedmassen på fastlandssiden; på Engelø er syken kun forekommet i spredte, meget få tilfælde og på Lundø aldeles ikke, så vidt jeg kunnet bringe til erfaring.

\section{«Til selve Steigen kom sygdommen først i november»}

Hvad komplikationer angår, gir tællingen som resultat, at av de 34 mænd over 15 år har 18 havt orchit - altså 53 pct. - et tal, der er adskillig større end almindelig ved epidemier. Granier (citeret hos Eichhorst) har 23 pct. -115:495- og Winge 17 pct. -35: 202 -. Og endda mener en av tællerne, at enkelte mænd av undseelse ikke vilde ut med sin orchit, så tallet er for lite.

En anden temmelig besværlig komplikation har været brækninger, dels de første dage, dels efter at hævelsen var gåt tilbake. Hvor hyppigt dette har forekommet, savner jeg oplysninger om. Brækninger er, så vidt jeg vet, udelukkende optrådt hos børn og har varet flere dager, så tilstanden stundom har været foruroligende, da barnet ikke har kunnet ta næring til sig. 
Diarre har været temmelig hyppig som eftersygdom også hos voksne og har flere gange nødet patienterne til at søke læge.

Herpes på læber, næse, kinder er iagttat hos samtlige angrepne (5) i en familie, hos en av disse var også submaxillarglanderne hovne.

En gang er iagtatt ensidig facialisparese hos en kone 3 uker efter sygdommens ophør.

To gange forekom kusma sammen med difteri. En voksen pike, hvor belægget var svundet, men med svælgparalyse, fikk kusma; hos en 6 års gut synes begge sygdomme at være optrådt samtidig. Første dag kunde jeg ikke med sikkerhet diagnosticere difteri, da gutten ikke kunde åpne munden, så han måtte isoleres på mistanke; næste dag, da han kunde gape, var diagnosen let. I ingen av tilfældene kunde det skønnes, at den ene sygdom influerte på den anden.

I ett tilfælde optrådte efter en parotit med alvorlige almensymptomer og orchit hos en 27 års mand en langvarig anæmisk tilstand med sterkt uttalte nervøse og psykiske symptomer: sterk depressio animi, søvnløshet, merkelige fornemmelser av vekslende art, nedsat syn, hørsel og følelse amed halvsidig karakter; under et besøk påvistes en anæsthetisk flek av en barnehånds størrelse i høire regio umbilicalis. Han skal ha havt «mavekatarrh» (motesygdommen her i distriktet - nevrastehni) og beskrives som noget "forsagt» av sig.

Hvad diagnosen angår, så har den ingen vanskelighet voldt. Som regel har patienterne selv gjort op diagnosen. I ett tilfælde vilde jeg dog uten epidemien som bakgrund ha kommet til at stille prognosen adskillig verre, end jeg gjorde. Det gjaldt en 8 års gut, der i 2 dage hadde havt febrilia med hodepine, brækninger, delirier. P. 100, T. 39, Intet lokalt at finde uten lidt smerte og ømhet for tryk i venstre øreregion - men ingen hævelse. To dage senere fik jeg bud, der bekræftede diagnose og prognose.

Tilslut et eksempel på, at denne sygdom, som i almindelighet blir set på med dyp foragt, ikke altid optræder bare humoristisk vansirende. Forretningsmand, 34 år, blev syk. (...) det viste sig ved veining at han paa de $12 \mathrm{~d} ø$ gn, han hadde været syk, var minket 7 kilo! - hvad han forøvrigt godt kunde avse og snart tok igjen.

Publisert: 7. desember 2021. Tidsskr Nor Legeforen. DOI:10.4045/tidsskr.21.0704

(C) Tidsskrift for Den norske legeforening 2023. Lastet ned fra tidsskriftet.no 26. april 2023. 